\title{
Regulation of Neuronal Stem Cell Proliferation in the Hippocampus by Endothelial Ceramide
}

\author{
Anne Gulbins ${ }^{a}$ Heike Grassmé ${ }^{b}$ Richard Hoehnc Barbara Wilker ${ }^{b}$ \\ Matthias Soddemann ${ }^{b}$ Marcus Kohnen ${ }^{a}$ Michael J. Edwards ${ }^{c}$ \\ Johannes Kornhuber ${ }^{d}$ Erich Gulbins ${ }^{b, c}$ \\ aGymnasium Essen-Werden, Essen, bDept. of Molecular Biology, Medical School, University of Duisburg- \\ Essen, Essen, Germany; 'Dept. of Surgery, University of Cincinnati, College of Medicine, University of \\ Cincinnati, Cincinnati, OH, USA; dDepartment of Psychiatry and Psychotherapy, University Hospital, \\ Friedrich-Alexander-University Erlangen-Nuremberg, Erlangen, Germany
}

\section{Key Words}

Neuronal stem cells $\bullet$ Endothelial cells $•$ Acid sphingomyelinase $\cdot$ Ceramide P Proliferation

\begin{abstract}
Background/Aims: Major depressive disorder is one of the most common diseases in western countries. The disease is mainly defined by its psychiatric symptoms. However, the disease has also many symptoms outside the central nervous system, in particular cardiovascular symptoms. Recent studies demonstrated that the acid sphingomyelinase/ceramide system plays an important role in the development of major depressive disorder and functions as a target of antidepressants. Methods: Here, we investigated (i) whether ceramide accumulates in endothelial cells in the neurogenetic zone of the hippocampus after glucocorticosteronemediated stress, (ii) whether ceramide is released into the extracellular space of the hippocampus and (iii) whether extracellular ceramide inhibits neuronal proliferation. Ceramide was determined in endothelial cell culture supernatants or extracellular hippocampus extracts by a kinase assay. Endothelial ceramide in the hippocampus was analyzed by confocal microscopy of brain sections stained with Cy3-labelled anti-ceramide antibodies and FITC-Isolectin B4. Neuronal proliferation was measured by incubation of pheochromocytoma neuronal cells with culture supernatants and extracellular hippocampus extracts. Results: Treatment of cultured endothelial cells with glucocorticosterone induces a release of ceramide into the supernatant. Likewise, treatment of mice with glucocorticosterone triggers a release of ceramide into the extracellular space of the hippocampus. The release of ceramide is inhibited by concomitant treatment with the antidepressant amitriptyline, which also inhibits the activity of the acid sphingomyelinase. Studies employing confocal microscopy revealed that ceramide is formed and accumulates exclusively in endothelial cells in the hippocampus of stressed mice, a process that was again prevented by co-application of amitriptyline. Ceramide released in the culture supernatant or into the extracellular space of the hippocampus reduced proliferation of neurons in vitro. Conclusion: The data suggest a novel model for the pathogenesis of major depressive disorder, i.e. the release of ceramide-enriched microvesicles from endothelial


cells that negatively affect neuronal proliferation in the hippocampus, but may also induce cardiovascular disease and other systemic symptoms of patients with major depressive disorder.

\section{Introduction}

Major depressive disorder, also named endogenous depression, is one of the most common diseases with a lifetime prevalence of more than $10 \%[1,2]$. Approximately $10 \%$ of patients with severe major depressive disorder attempt suicide resulting in a significant mortality of the disease $[1,3]$. It is therefore surprising that the molecular mechanisms that lead to such a severe, common and often chronic disease are largely unknown. The disease is usually defined by its psychiatric symptoms such as depressed mood, melancholia, inability to feel, loss of interest, anhedonia, fear, feelings of worthlessness, weight loss, insomnia, and concentration deficits [1-3]. However, most patients also suffer from symptoms that affect the cardiovasular system such as high blood pressure, heart disease and arteriosclerosis, but also osteoporosis, loss of weight and metabolic changes such as adrenocortical activation, increased plasma concentrations of proinflammatory cytokines, low serum HDL cholesterol concentrations and a dysfunction of the hypothalamic-pituitary-adrenal axis [4-11].

It is unclear how these systemic changes are induced by isolated alterations of the central nervous systems and it might be more appropriate to envision major depressive disorder as a systemic disease [12].

Many antidepressants inhibit the uptake of monoaminergic transmitters and based on this finding it was postulated that major depressive disorder is caused by low concentrations of monoaminergic transmitters in the synaptic space. However, this monoaminergic hypothesis of major depression fails to explain the delayed onset of the therapeutic effects of antidepressants, which usually reduce the symptoms after 2-4 weeks of treatment, since the increase of neurotransmitters in the synaptic space is rapidly induced by these drugs [13]. Further, some antidepressants, for instance tianeptine, even promote neurotransmitter uptake [14]. Therefore novel concepts to explain major depressive disorder were developed and recent concepts focus on a reduced neurogenesis in the hippocampus as one of the major pathogenetic mechanisms for major depressive disorder [15-19]. The human brain produces approximately 700 neurons daily, mainly in the hippocampus and the prefrontal cortex $[16,17]$. It is assumed that major depressive disorder is caused, at least in part, by a reduction of neurogenesis in the hippocampus. This is consistent with clinical findings demonstrating a size-reduction of the hippocampus in patients with major depression and animal models showing a reduced neurogenesis in stress-induced major depression [20-22]. The reduced neurogenesis in the hippocampus in patients with major depression might result in a rarefication of neuronal networks and finally the functional failure of these networks with the consequence of major depression $[3,12,18]$. Antidepressants increase neurogenesis and neuronal maturation thereby restoring these networks $[18,19,23]$, which requires 2-4 weeks, a time frame that is in accordance with the delayed actions of antidepressants. On a molecular basis we were recently able to show that antidepressants increase neurogenesis by an inhibition of the acid sphingomyelinase/ceramide system [12]. The acid sphingomyelinase is an ubiquitously expressed enzyme that cleaves sphingomelin to generate ceramide $[24,25]$. Ceramide inhibits proliferation in most cells or even induces cell death [26]. The inhibition of the acid sphingomyelinase by antidepressants results in a reduction of ceramide and thereby in an increase of neurogenesis in the hippocampus [12, 27].

Many patients with major depressive disorder also show increased levels of glucocorticoids in the blood, which might reduce neurogenesis [28, 29]. However, not all patients show an alteration of glucocorticoid-levels and thus a simple increase of glucocorticoids does not explain the full clinical picture of major depressive disorder [28, 29]. However, prolonged application of glucocorticoids is a good model to induce many symptoms of major depression in animal studies and is widely used as stress model [12].

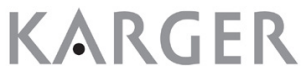




\section{Cellular Physiology Cell Physiol Biochem 2016;39:790-801 \begin{tabular}{c|c|c|} 
DOI: 10.1159/000447789 & O 2016 The Author(s). Published by S. Karger AG, Basel \\
www.karger.com/cpb
\end{tabular} \\ Gulbins et al.: Endothelial Ceramide Regulates Hippocampal Stem Cells}

The underlying pathogenesis of major depressive disorder is still unknown. It is also unknown how stress affects neuronal stem cells in the hippocampus and regulates their proliferation. Further, major depressive disorder seems to be a systemic disease that affects many organs and not just the brain or even selectively the hippocampus. Therefore, we investigated whether a stress-induced major depression alters the activity of the acid sphingomyelinase/ceramide system in endothelial cells, whether such an alteration is corrected by antidepressants and whether ceramide released by endothelial cells is able to regulate neuronal proliferation. Such a change of ceramide in endothelial cells might also explain the extraneural symptoms of major depressive disorder.

\section{Materials and Methods}

\section{Mice}

C57BL/6 wildtype mice were treated for 14 days with $250 \mathrm{mg} / \mathrm{L}$ glucocorticosterone in $0.9 \% \mathrm{NaCl}$ used as drinking water. Glucocorticosterone was dissolved at $125 \mathrm{mg} / \mathrm{mL}$ in dimethylsulfoxide and then further diluted. Amitriptyline was applied at $120 \mathrm{mg} / \mathrm{L}$ in $0.9 \% \mathrm{NaCl}$ as drinking water [12]. Amitriptyline application was started 2 days after initiation of the glucocorticosterone. All studies were performed in accordance with animal permissions of the Regierungspraesidium Düsseldorf and the Institutional Animal Care and Use Committee, Cincinnati.

\section{Chemicals}

All Chemicals were from Sigma-Aldrich if not otherwise noted.

Endothelial (bEnd3) cells

bEnd3 cells were obtained from ATCC and grown in RPMI-1640, 10 mM HEPES (pH 7.4, Carl Roth $\mathrm{GmbH}$ ), $2 \mathrm{mM}$ L-glutamine, $1 \mathrm{mM}$ sodiumpyruvate, $100 \mu \mathrm{M}$ non-essential amino acids, $100 \mathrm{U} / \mathrm{mL}$ penicillin, $100 \mu \mathrm{g} / \mathrm{mL}$ streptomycin (all from Invitrogen) and $10 \%$ fetal calf serum (PAA Laboratories $\mathrm{GmbH}$ ) at $37^{\circ} \mathrm{C}$ and $5 \% \mathrm{CO}_{2}$. Prior to treatment with glucocorticosterone the cells were transferred to 24 well plates. After the indicated treatment, the supernatants were removed, centrifuged for $10 \mathrm{~min}$ at $1000 \mathrm{xg}$ to pellet cells, the supernatants were transferred into new tubes and shock-frozen in liquid nitrogen.

Neuronal pheochromocytoma-12 (PC-12) cells

PC-12 cells were grown in RPMI-1640, 10 mM HEPES, 2 mM L-glutamine, 1 mM sodiumpyruvate, 100 $\mu \mathrm{M}$ non-essential amino acids, $100 \mathrm{U} / \mathrm{mL}$ penicillin, $100 \mu \mathrm{g} / \mathrm{mL}$ streptomycin and $10 \%$ fetal calf serum at $37^{\circ} \mathrm{C}$ and $5 \% \mathrm{CO}_{2}$. To determine the effect of ceramide on the proliferation of PC-12 cells, the cells were incubated for $48 \mathrm{hrs}$ with (i) $10 \mu \mathrm{M} \mathrm{C16}$ ceramide, (ii) cell culture supernatants from glucocorticosterone, glucocorticosterone + amitriptyline or amitriptyline treated or untreated endothelial cells or (iii) with extracts (see below) of the hippocampus of mice that were either left untreated or treated with amitriptyline, glucocorticosterone or glucocorticosterone + amitriptyline. To this end, the PC-12 cells were aliquoted and resuspended in the cell culture supernatants. C16 ceramide or brain extracts were directly added to the PC-12 cells in the medium above. The experiment started with 200000 cells/mL medium. Proliferation was measured after $48 \mathrm{hrs}$ incubation by counting the cell numbers in a Neubauer-chamber. In addition, cells were labelled with $\left[{ }^{3} \mathrm{H}\right]$ Thymidine during the treatment. Cells were washed after $48 \mathrm{hrs}$ incubation and the cells were lysed in distilled water. The DNA was then pelleted, washed and incorporation of $\left[{ }^{3} \mathrm{H}\right]$ Thymidine was determined by liquid scintillation counted.

\section{Hippocampus extracts}

Mice were sacrificed, the brain removed, the hippocampus carefully exposed and the tissue was homogenized in $300 \mu \mathrm{L}$ HEPES/Saline (H/S) $132 \mathrm{mM} \mathrm{NaCl}, 20 \mathrm{mM}$ HEPES [pH 7.4], $5 \mathrm{mM} \mathrm{KCl,} 1 \mathrm{mM} \mathrm{CaCl}_{2^{\prime}}$ $0.7 \mathrm{mM} \mathrm{MgCl}_{2}, 0.8 \mathrm{mM} \mathrm{MgSO}_{4}$ ) in a loose Dounce homogenizer. This method left the cells intact, which was confirmed by Trypan blue staining, but resulted in complete homogenization of the tissue. Cells were pelleted by a $10 \mathrm{~min}$ centrifugation at $1000 \mathrm{xg}, 4^{\circ} \mathrm{C}$, the supernatants were collected and shock-frozen in liquid nitrogen. 


\section{Cellular Physiology Cell Physiol Biochem 2016;39:790-801 \begin{tabular}{l|l|l}
\hline DOI: 10.1159/000447789 & $\begin{array}{l}\text { C } 2016 \text { The Author(s). Published by S. Karger AG, Basel } \\
\text { www.karger.com/cpb }\end{array}$
\end{tabular} \\ Gulbins et al.: Endothelial Ceramide Regulates Hippocampal Stem Cells}

Acid sphingomyelinase activity

Supernatants were thawed and $50 \mu \mathrm{L}$ aliquots were added to $300 \mu \mathrm{L}$ of a buffer consisting of $250 \mathrm{mM}$ sodiumacetate ( $\mathrm{pH} 5.0$ ) and $0.1 \% \mathrm{NP}-40$. The reaction was started by addition of $50 \mathrm{nCi}\left[{ }^{14} \mathrm{C}\right]$-sphingomyelin per sample (Perkin Elmer; $52 \mathrm{mCi} / \mathrm{mmol}$ ). To this end, the substrate $\left[{ }^{14} \mathrm{C}\right]$-sphingomyelin was dried in a speedvac, resuspended in $250 \mathrm{mM}$ sodiumacetate ( $\mathrm{pH} \mathrm{5.0)}$ and $0.1 \%$ NP-40 and bath sonicated for 10 min to obtain micelles. The samples were incubated for $60 \mathrm{~min}$ at $37^{\circ} \mathrm{C}$, extracted in $800 \mu \mathrm{L} \mathrm{CHCl}_{3}: \mathrm{CH}_{3} \mathrm{OH}$ $(2: 1, \mathrm{v} / \mathrm{v})$, phases were separated and the radioactivity in an aliquot of the upper phase was determined by liquid scintillation counting. The activity of the acid sphingomyelinase results in the release of $\left[{ }^{14} \mathrm{C}\right]-$ phosphorylcholine from $\left[{ }^{14} \mathrm{C}\right]$-sphingomyelin. Since $\left[{ }^{14} \mathrm{C}\right]$-phosphorylcholine is water soluble, while $\left[{ }^{14} \mathrm{C}\right]-$ sphingomyelin is not, they can be easily separated and the amount of $\left[{ }^{14} \mathrm{C}\right]$-phosphorylcholine in the aqueous phase allows to calculate the enzyme activity.

\section{Sphingosine kinase activity}

To measure the activity of sphingosine kinases in the above described endothelial cell supernatants, $50 \mu \mathrm{L}$ of the supernatants were added to $100 \mu \mathrm{L}$ kinase assay buffer consisting of $50 \mathrm{mM}$ HEPES (pH 7.4), $250 \mathrm{mM} \mathrm{NaCl}, 30 \mathrm{mM} \mathrm{MgCl} 21 \mathrm{mM} \mathrm{ATP}, 10 \mu \mathrm{Ci}\left[{ }^{32} \mathrm{P}\right] \gamma \mathrm{ATP}$ and $2 \mathrm{nmol}$ sphingosine (Avanti-Polar Lipids). Samples were incubated for $60 \mathrm{~min}$ at $37^{\circ} \mathrm{C}$, stopped by addition of $20 \mu \mathrm{L} 1 \mathrm{~N} \mathrm{HCl}$ and extracted in $800 \mu \mathrm{L}$ $\mathrm{CHCl}_{3} / \mathrm{CH}_{3} \mathrm{OH} / 1 \mathrm{~N} \mathrm{HCl}(100: 200: 1, \mathrm{v} / \mathrm{v} / \mathrm{v})$, followed by addition of each $240 \mu \mathrm{L} \mathrm{CHCl}_{3}$ and $2 \mathrm{M} \mathrm{KCl}$. The lower phase was collected, dried, dissolved in $20 \mu \mathrm{L} \mathrm{CHCl}: \mathrm{CH}_{3} \mathrm{OH}(1: 1, \mathrm{v} / \mathrm{v})$, spotted onto Silica G60 TLC-plates and the samples were developed using $\mathrm{CHCl}_{3} / \mathrm{CH}_{3} \mathrm{OH} /$ acetic acid/ $\mathrm{H}_{2} \mathrm{O}$ (90:90:15:5, v/v/v/v). TLC-plates were analyzed in a phosphoimager and the activity of sphingosine kinase was calculated by comparison of the values with a standard curve using defined amounts of sphingosine and recombinant sphingosine kinase (R\&D).

\section{Ceramide measurements}

$150 \mu \mathrm{L}$ aliquots of the cell supernatants or hippocampus extracts were added to $600 \mu \mathrm{L} \mathrm{CHCl}_{3}: \mathrm{CH}_{3} \mathrm{OH}: 1 \mathrm{~N}$ $\mathrm{HCl}(100: 100: 1, \mathrm{v} / \mathrm{v} / \mathrm{v})$. Phases were separated, the lower phase was collected, dried, lipids were resuspended in $20 \mu \mathrm{L}$ of a detergent solution consisting of $7.5 \%$ (w/v) n-octyl-glucopyranoside and $5 \mathrm{mM}$ cardiolipin in $1 \mathrm{mM}$ diethylentriaminpentaceticacid (DTPA), $10 \mathrm{~min}$ sonicated in a bath sonicator and the kinase reaction was started by addition of $70 \mu \mathrm{L}$ kinase buffer consisting of $10 \mu \mathrm{L}$ diacylglycerol (DAG) kinase (GE Healthcare Europe, Munich, Germany), 0.1 M imidazole/HCl (pH 6.6), $0.2 \mathrm{mM}$ DTPA (pH 6.6), $70 \mathrm{mM} \mathrm{NaCl}, 17 \mathrm{mM} \mathrm{MgCl}, 1.4 \mathrm{mM}$ ethylene glycol tetraacetic acid, $2 \mathrm{mM}$ dithiothreitol, $1 \mu \mathrm{M}$ adenosine triphosphate (ATP), and $10 \mu \mathrm{Ci}\left[{ }^{32} \mathrm{P}\right] \gamma \mathrm{ATP}$. The kinase reaction was performed for $60 \mathrm{Min}$ at $22^{\circ} \mathrm{C}$, samples were then extracted in $1 \mathrm{~mL} \mathrm{CHCl}{ }_{3}: \mathrm{CH}_{3} \mathrm{OH}: 1 \mathrm{~N} \mathrm{HCl}(100: 100: 1, \mathrm{v} / \mathrm{v} / \mathrm{v}), 170 \mu \mathrm{L}$ buffered salt solution (135 $\mathrm{mM} \mathrm{NaCl}, 1.5 \mathrm{mM} \mathrm{CaCl}_{2}, 0.5 \mathrm{mM} \mathrm{MgCl}_{2}, 5.6 \mathrm{mM}$ Glucose, $10 \mathrm{mM}$ HEPES [pH 7.2]) and $30 \mu \mathrm{L}$ of $100 \mathrm{mM}$ EDTA. Phases were separated, the lower phase was collected, dissolved in $20 \mu \mathrm{L} \mathrm{CHCl}_{3}: \mathrm{CH}_{3} \mathrm{OH}(1: 1, \mathrm{v} / \mathrm{v})$ and lipids were separated on Silica G60 TLC plates using chloroform/acetone/methanol/acetic acid/ $\mathrm{H}_{2} \mathrm{O}$ (50:20:15:10:5, v/v/v/v/v). TLC-plates were analyzed on a phosphoimager and ceramide amounts were determined by a standard curve with defined amounts of C16 und C24 ceramide as substrate.

Immunohistochemical analysis of ceramide in endothelial cells of the hippocampus

Mice were sacrificed, brains were removed and immediately shock-frozen in Tissue-Tek. Frozen sections of the brain were obtained, dried on air for $5 \mathrm{~min}$, fixed in ice-cold acetone for $10 \mathrm{~min}$, washed 3-times in PBS (137 mM NaCl, $2.7 \mathrm{mM} \mathrm{KCl}, 10 \mathrm{mM} \mathrm{Na}_{2} \mathrm{HPO}_{4}$ and $1.8 \mathrm{mM} \mathrm{KH}_{2} \mathrm{PO}_{4}$ ) and unspecific binding sites were blocked in $\mathrm{H} / \mathrm{S}+5 \% \mathrm{FCS}$. The sections were washed and incubated with anti-ceramide-antibodies (Glycobiotech; 1:100 diluted in $\mathrm{H} / \mathrm{S}+1 \% \mathrm{FCS}$ ) for $45 \mathrm{~min}$ at room temperature. The samples were then washed 3-times in PBS + 0.05\% Tween 20 for each 5 min, once in PBS and stained with a Cy3-labelled antimouse-IgM antibody. The samples were washed again 3-times, 5 min each in PBS $+0.05 \%$ Tween 20 and once in PBS and were then incubated for $12 \mathrm{hrs}$ at $4^{\circ} \mathrm{C}$ with FITC-labelled Isolectin B4 (1:50 in H/S + 1\% FCS diluted). Samples were washed again as above, embedded in Mowiol and analyzed on a Leica TCS DMIRE.

Statistical analysis

Data are shown as mean \pm SD and examined with analysis of variance (ANOVA) and post hoc tests. A $P$ value of 0.05 or less (two-tailed) was considered indicative of statistical significance. 


\section{Cellular Physiology Cell Physiol Biochem 2016;39:790-801

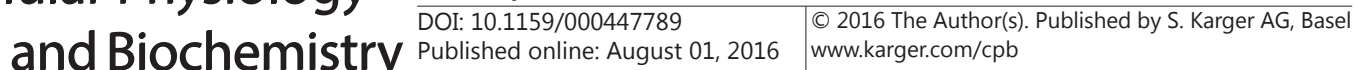 \\ Gulbins et al.: Endothelial Ceramide Regulates Hippocampal Stem Cells}

\section{Results}

To test whether endothelial cells release ceramide into the extracellular space upon treatment with glucocorticoids, we incubated bEnd3 endothelial cells with glucocorticosterone for $48 \mathrm{hrs}$ and determined the concentration of ceramide in the supernatant. To this end, any remaining cells present in the supernatants were pelleted by centrifugation, the supernatants were collected and lipids were extracted from these supernatants. Ceramide was then quantified employing a ceramide-kinase assay. The studies revealed a marked release of ceramide from the glucocorticoid-stressed endothelial cells (Fig. 1). Treatment of the endothelial cells with amitriptyline, a functional blocker of the acid sphingomyelinase [27, 30,31] and well-established antidepressant, prevented the release of ceramide induced by glucocorticoids and even reduced the baseline release of ceramide from endothelial cells (Fig. 1).

Next, we investigated whether stressed endothelial cells also release acid sphingomyelinase and/or sphingosine kinase in addition to ceramide. Release of the acid sphingomyelinase would promote stress by further generation of ceramide, while release of sphingosine kinase would counteract stress by generation of sphingosine 1-phosphate as recently shown for hepatocytes after ischemia/reperfusion injury [32]. However, we were unable to detect measurable amounts of acid sphingomyelinase or sphingosine kinase in the supernatant of glucocorticosterone-stressed endothelial cells (not shown).

To translate the in vitro findings into the in vivo situation, we tested whether we are able to detect ceramide-containing microvesicles in the hippocampus of stressed, amitriptylinetreated or unstressed mice.

To this end, we prepared the hippocampus, homogenized the tissue in a loose dounce homogenizer, pelleted cells and determined ceramide in the supernatants. Trypan Blue

Fig. 1. Cultured endothelial cells release ceramide after glucocorticoid-mediated stress. bEnd3-endothelial cells were incubated for 48 hrs with glucocorticosterone, the supernatants were removed, cells were pelleted and ceramide was determined in the supernatants. Glucocorticosterone induced a marked release of ceramide from the endothelial cells into the extracellular medium, which was blocked by co-incubation with amitriptyline, an inhibitor of the acid sphingomyelinase. Shown are the mean \pm SD of each 6 independent samples. * $\mathrm{p}<0.05$ for significant differences compared to untreated controls and $\Delta \mathrm{p}<0.05$ for significant differences compared to glucocorticosterone alone, ANOVA.

Fig. 2. Ceramide is increased in extracellular extracts of the hippocampus of stressed mice. Mice were treated with glucocorticosterone, amitripytline or glucocorticosterone + amitriptyline or left untreated. The hippocampus was removed, carefully homogenized, cells were pelleted and ceramide in the supernatants was measured by a kinase assay. The data reveal that ceramide is present in the extracellular space of the hippocampus. Extracellular ceramide is increased after treatment of the mice with glucocorticosterone. Amitriptyline prevents the effects of glucocorticosterone on the extracellular release of ceramide in the hippocampus. Shown are the mean \pm SD of each 5 mice, ${ }^{*} \mathrm{p}<0.05$ compared to untreated mice, $\mathrm{p}<0.05$ compared to glucocorticosterone alone, ANOVA.
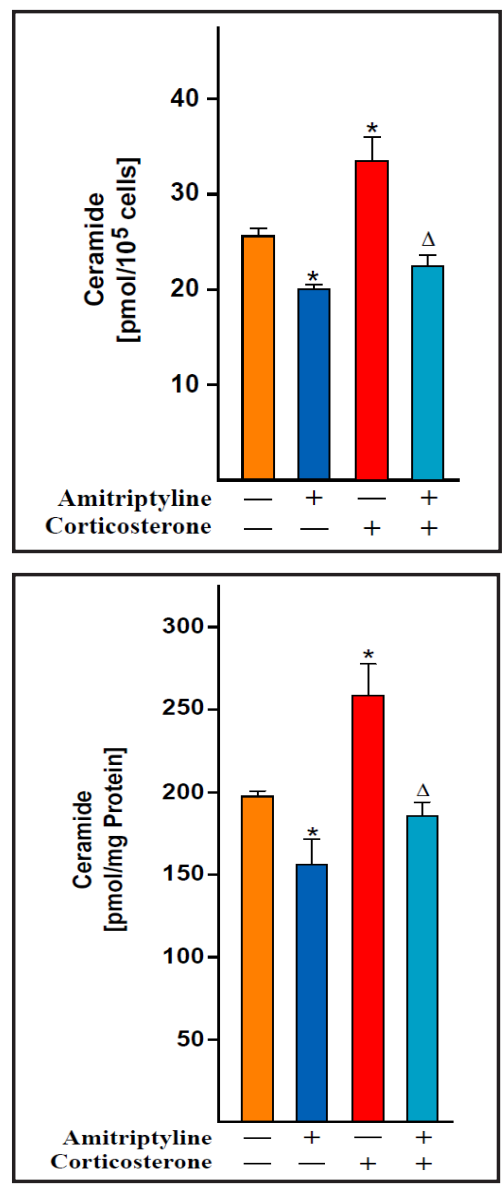
Fig. 3. Ceramide accumulates in endothelial cells in the neurogenetic zone of the hippocampus. Untreated mice show low levels of ceramide within the endothelial cells of the neurogenetic zone of the hippocampus, which is even further reduced by amitriptyline (A, C). Glucocorticosterone markedly increases the levels of ceramide within these endothelial cells, an effect that is prevented by co-treatment of the mice with amitriptyline (B, C). Brain sections were stained with FITCconjugated Isolectin B4 that specifically binds to endothelial cells and Cy3-labelled anti-ceramideantibodies and analyzed by confocal microscopy. Displayed are the single stainings and the overlays (right panels). Panel C shows enlarged areas of interests of the overlays in A and B. Demonstrated are representative results from each 6 mice per group. The co-localization of endothelial cells (green) and ceramide (red) in the overlays appears in yellow and is indicated by arrows.

stainings confirmed the integrity of the cells after homogenization. These experiments revealed the presence of ceramide in these hippocampus extracts (Fig. 2). Since ceramide is insoluble in water, it is most likely that ceramide is present in microvesicles. Treatment with glucocorticosterone markedly increased the concentration of ceramide/ceramide-enriched microvesicles in the hippocampus extracts, which was normalized by treatment with ami-

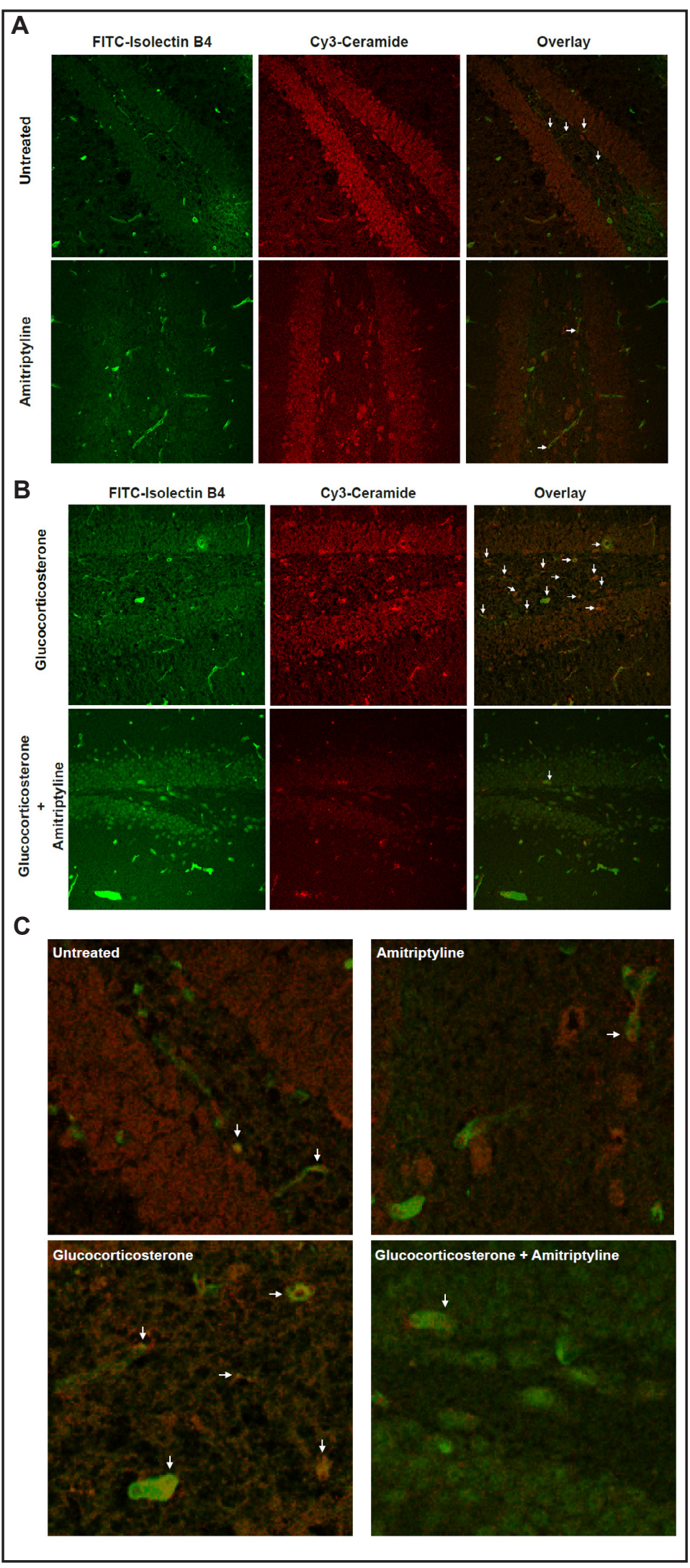
triptyline (Fig. 2). Amitriptyline reduced the concentration of ceramide in extracellular hippocampus extracts even in non-stressed mice (Fig. 2). 
Fig. 4. C16 ceramide, ceramide-enriched cell culture supernatants or hippocampus extracts inhibit the proliferation of neurons. Treatment of neuronal PC-12 pheochromocytoma cells with $10 \mu \mathrm{M}$ C16 ceramide, supernatants (Sup.) from glucocorticosterone-treated (tr.) bEnd3-endothelial cells (A, B) or hippocampal extracts from glucocorticosterone-treated mice (C, D) inhibits proliferation of neurons. Concomitant application of amitriptyline prevents glucocorticosterone-induced release of ceramide by bEnd3 cells and within the hippocampus of cells or mice, respectively (A-D). Amitriptyline alone was without effect on proliferation (A-D). Addition of anti-ceramide-antibodies (indicated as anti-ceramide) to the hippocampus extracts from stressed mice prevented the inhibitory effect of these extracts on cell proliferation (C, D). Glucocorticosterone added to cell culture supernatants (indicated as Sup. + Corticosterone) obtained from untreated bEnd3-endothelial cells was without effect on the proliferation of PC-12 cells (A, B). Cell proliferation was measured by Trypan-Blue staining and counting cells daily in a Neubauer-chamber $(\mathrm{A}, \mathrm{C})$ and by $\left[{ }^{3} \mathrm{H}\right]$ Thymidine-labelling of the cells followed by extraction of the DNA (B, D). Shown are the mean \pm SD of each 6 cells or 5 mice, respectively, ${ }^{*} \mathrm{p}<0.05$ compared with the untreated controls and, $\Delta$ or \# $\mathrm{p}<0.05$ compared with corticosterone alone, ANOVA.

Todemonstratethatceramide is increased in endothelial cells of the hippocampus after stress and normalized within these cells upon treatment with amitriptyline, we stained sections of the hippocampus with Cy3coupled anti-ceramide-antibodies and FITC-conjugated Isolectin B4 that specifically binds to endothelial cells [33]. Confocal microscopy studies revealed that

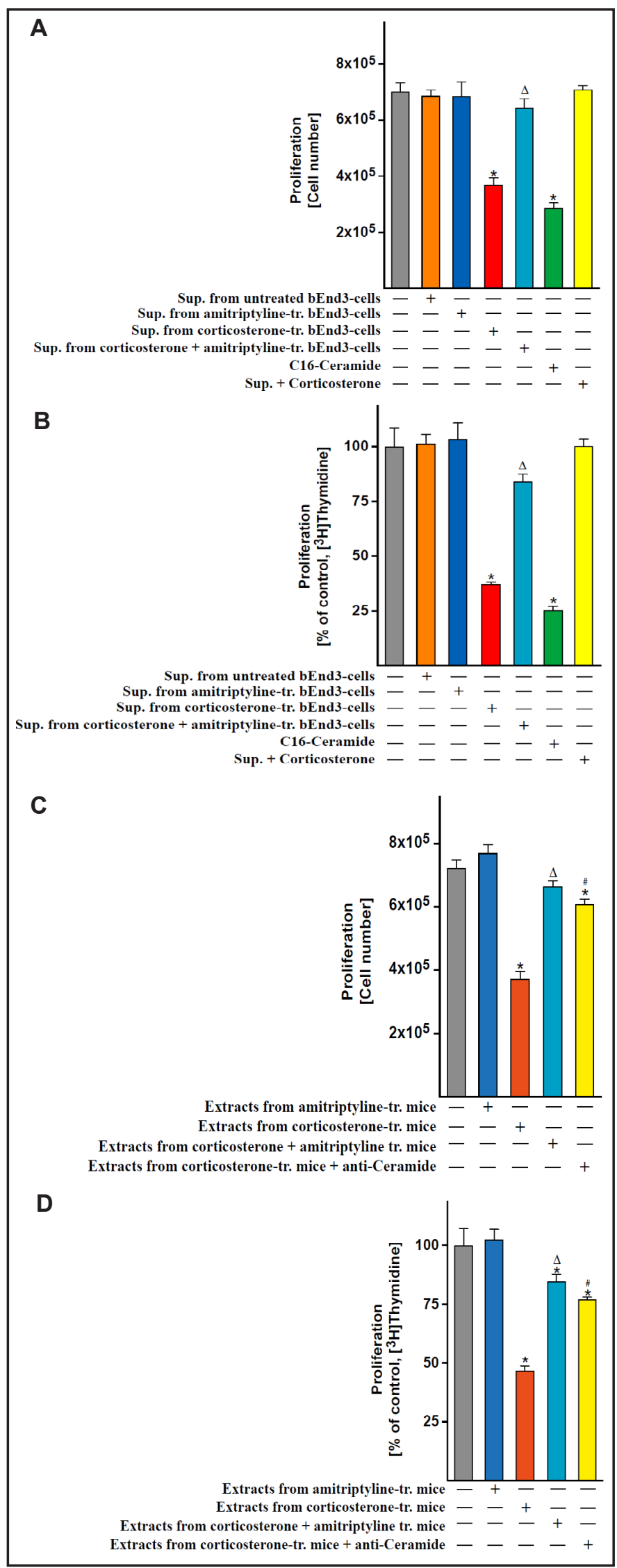




\section{Cellular Physiology Cell Physiol Biochem 2016;39:790-801 and Biochemistry Published online: August 01, $2016 \quad \begin{aligned} & \text { C } 2016 \text { The Author(s). Published by S. Karger AG, Basel } \\ & \text { www.karger.com/cpb }\end{aligned}$ \\ Gulbins et al.: Endothelial Ceramide Regulates Hippocampal Stem Cells}

ceramide increased in endothelial cells of the hippocampus after treatment of the mice with glucocorticosterone (Fig. 3A-C). This increase was prevented by concomitant treatment of the mice with amitriptyline (Fig. 3A-C).

These data demonstrate that ceramide is released within endothelial cells of the hippocampus upon stress and that amitriptyline normalized endothelial ceramide concentrations in stressed mice. Further, ceramide is detected in the extracellular space of the hippocampus, most likely in microparticles.

We therefore investigated whether ceramide-containing hippocampus extracts, ceramide-containing endothelial cell culture supernatants or pure C16 ceramide influence the proliferation of neuronal cells. To this end, neuronal PC-12 pheochromocytoma cells were incubated with $10 \mu \mathrm{M}$ ceramide, supernatants of bEnd3 endothelial cells or hippocampus extracts of mice, respectively, treated with glucocorticosterone, amitriptyline or glucocorticosterone + amitriptyline. Controls were neuronal PC-12 cells incubated with supernatants or hippocampus extracts from untreated bEnd3 endothelial cells or mice, respectively. Ceramide was neutralized by addition of anti-ceramide antibodies to the extracts. Further, we added glucocorticosterone to the cell culture supernatants from untreated endothelial cells to exclude an effect of the glucocorticosterone only.

The experiments revealed that C16 ceramide, ceramide-containing cell culture supernatants from stressed endothelial cells and microparticles from the hippocampus of glucocorticosterone-stressed mice inhibited the proliferation of neuronal PC-12 cells (Fig. 4A-D). In contrast, supernatants, from bEnd3-endothelial cells or extracts from the hippocampus of mice, respectively, that were treated with glucocorticosterone + amitriptyline did not affect proliferation of neuronal PC-12 cells (Fig. 4A-D). Supernatants or hippocampus extracts from bEnd3-endothelial cells or mice, respectively, treated with amitriptyline only, were without effect on the proliferation of PC-12 cells (Fig. 4A-D). Likewise, addition of glucocorticosterone to supernatants after their isolation from untreated bEnd3-endothelial cells did not alter proliferation of PC-12 cells (Fig. 4A-D), excluding that glucocorticosterone by itself mediated the effects on proliferation. Neutralization of ceramide in the hippocampus extracts from stressed mice by addition of anti-ceramide antibodies prevented the growth inhibitory effect on PC-12 cells of these extracts.

\section{Discussion}

Here we provide a novel concept for the genesis of central nervous and systemic, extraneural symptoms on patients with major depressive disorder: We demonstrate that glucocorticosterone-stressed endothelial cells release ceramide, which is prevented by amitriptyline. Most importantly, endothelial cells of small vessels in the neurogenetic zone of the hippocampus accumulate ceramide upon stressing the mice with glucocorticosterone, an alteration that is also prevented by co-treatment of the mice with amitriptyline, a wellknown and often-used antidepressant and functional inhibitor of the acid sphingomyelinase [27]. The accumulation of endothelial ceramide correlates with a release of ceramide into the extracellular space of the hippocampus in stressed mice, which is reduced to basal levels by treatment with amitriptyline. Both, the supernatants of stressed endothelial cells as well as the extracts from the hippocampus of stressed mice reduced neuronal proliferation, which was restored by treatment of the endothelial cells or the mice, respectively, with amitriptyline or by neutralization of ceramide within the extracts using anti-ceramide antibodies.

Our data show that ceramide in the supernatant of endothelial cells or the extracellular space of the hippocampus regulates proliferation of neuronal cells. Antibodies neutralizing ceramide prevent this effect, which is in turn mimicked by C16-ceramide, a natural ceramide that is often involved in the mediation of stress [3] and that has been shown to reduce neuronal proliferation after direct injection into the hippocampus [12]. Since ceramide is insoluble in water it can only exist in the aqueous extracellular phase as a part of exosomes, microparticles or in micelles. It is beyond the focus of the present manuscript to exactly define 


\section{Cellular Physiology Cell Physiol Biochem 2016;39:790-801 and Biochemistry Published online: August 01, $2016 \quad \begin{aligned} & \text { DOI: 10.1159/000447789 } 2016 \text { The Author(s). Published by S. Karger AG, Basel } \\ & \text { www.karger.com/cpb }\end{aligned}$ \\ Gulbins et al.: Endothelial Ceramide Regulates Hippocampal Stem Cells}

the nature of the vesicles that contain ceramide released by endothelial cells upon stress. Therefore, we use the terminology microvesicles. Microvesicles are often characterized by their source and size: Microparticles are released from the plasma membrane, a process that requires activity of the acid sphingomyelinase [34]. They are usually pelleted at 25,000xg. Exosomes are smaller than microparticles and pellet at 100,000xg. They are released upon fusion of multivesicular bodies with the plasma membrane, requiring activity of the neutral sphingomyelinase [35]. Microparticles were recently implied in the release of inflammatory mediators by glia cells [34] and also in ischemic damage of the brain [36] as well as Alzheimer degeneration [37]. However, a role of endothelial-derived extracellular ceramide in regulation of neuronal cell proliferation has not previously been shown.

It will be very interesting to determine the enzymes and mechanisms involved in the formation of ceramide containing vesicles as well as the exact nature of these vesicles released from endothelial cells upon stress. At present, the regulation of the release of microvesicles from endothelial cells by glucocorticoids is poorly characterized: A study by Thai et al. [38] demonstrated that dexamethasone triggers the release of annexin A1-containing microparticles from endothelial cells, while Zhu et al. [39] reported that dexamethasone inhibits the constitutive release of microparticles from human umbilical vein endothelial cells. We assume that different endothelial cell types show a different response to glucocorticoids, since the function of umbilical vein endothelial cells, a fenestrated renal endothelial cell and a very tight endothelial cell in the stem cell niche of the hippocampus, to name a few examples, have very different functions. Moreover, the effect of glucocorticoids on ceramide in microvesicles released by endothelial cells has not been investigated so far.

The present studies demonstrate a specific accumulation of ceramide in endothelial cells in the hippocampus and a release of ceramide into the extracellular space of the hippocampus upon application of stress and a correction of these stress effects by amitriptyline. Major depressive disorder is not only a disease of the brain with psychiatric symptoms, but also a systemic disease with cardiovascular symptoms or osteoporosis [1-11]. These symptoms cannot be explained by an isolated alteration of the hippocampal neurogenesis or a reduced concentration of neurotransmitters in the synaptic space. Here, we suggest a novel model to explain the various symptoms of major depressive disorder: The accumulation of ceramide within endothelial cells of the microcirculation results in the extracellular release of ceramide, in particular in ceramide-enriched microvesicles, that reduces proliferation of neuronal stem cells being in close vicinity to endothelial cells in the vascular-stem cell niche of the hippocampus. Endothelial ceramide has been shown to be critically involved in arteriosclerosis and heart disease [40-43], in accordance with the present concept. The present concept is also in accordance with the finding that direct injection of micellar ceramide into the hippocampus induces major depressive disorder symptoms in mice [12]. In addition, application of decanoylamino-3-morpholino-1-propanol (PDMP), which prevents glycosylation of ceramide and results in a cellular accumulation of ceramide induces major depressive-like symptoms in mice [12]. PDMP is, however, unable to cross the blood brain barrier, and therefore is only able to directly act on endothelial cells, but not on neuronal stem cells [44]. Finally, several studies demonstrated that Vascular Endothelial Growth Factor (VEGF), which promotes endothelial cell proliferation and stabilizes endothelial cells [45, 46], acts anti-depressive. Since VEGF inhibits the acid sphingomyelinase [47], it is possible that this anti-depressive effect of VEGF is related to inhibition of the acid sphingomyelinase/ ceramide system in endothelial cells. However, neuronal stem cells express VEGF-receptor 2 [48] and it is therefore also possible that VEGF does not only act on endothelial cells but also directly on neuronal stem cells after crossing the blood-brain barrier.

It is interesting to speculate how the acid sphingomyelinase in endothelial could be manipulated in addition to treatment with antidepressants or VEGF. It might be possible to change endothelial sphingolipids by nutrition [49], although it is not known whether these effects would be strong enough to reduce ceramide formation. It might be also possible that polymorphisms and the sex influence the activity of the acid sphingomyelinase in and the release of ceramide from endothelial cells $[50,51]$, in particular since major depression 
seems to be more common in women. However, the role of these factors for the release of ceramide from endothelial cells must be carefully explored and is beyond the focus of the present manuscript.

Extracellular ceramide may act on cells by changing the biophysical properties of biomembranes [52]. Ceramide integrates into membranes and forms large ceramideenriched membrane domains that are very hydrophobic, relatively rigid and almost in a gellike state $[52,53]$. These ceramide-enriched membrane platforms are able to trap and cluster stress receptors and associated signalling molecules, while other signalling molecules are excluded from these domains $[26,52,53]$. The clustering of stress receptors in ceramideenriched membrane domains might result in their activation and thereby in inhibition of cell proliferation and/or even cell death [26, 52, 53].

Previous data from our laboratory demonstrated that glucocorticosterone does not alter overall ceramide levels in the hippocampus and, moreover, also reduces neurogenesis and induces major depression in acid sphingomyelinase-deficient mice [12]. Acid sphingomyelinase-deficient mice do not respond to tricyclic antidepressants anymore [12] indicating that inhibition of the acid sphingomyelinase is required for the effects of these antidepressants. On the other hand, neurogenesis was reduced and major depression induced in acid sphingomyelinase-transgenic mice and acid ceramidase-heterozygous mice showing an increase of ceramide in the hippocampus due to the overproduction of ceramide or the reduced consumption of ceramide, respectively [12]. Direct injection of ceramide into the hippocampus had the same effects [12]. These data show that ceramide itself reduces neurogenesis and induces major depression symptoms. However, glucocorticosterone does not act via an activation of the acid sphingomyelinase, since it also induces major depression in acid sphingomyelinase-deficient mice [12]. Thus, glucocorticosterone could increase ceramide levels in endothelial cells observed in the present study by an activation of the neutral sphingomyelinase, the ceramide synthesis pathway or by an inhibition of ceramide metabolism/consumption. The amount of ceramide specifically produced and released in endothelial cells is too low to be detected in lysates of the whole hippocampus, while the local concentration of ceramide within the vascular niche of stem cells might be high enough to prevent stem cell proliferation [12]. Antidepressants inhibit the acid sphingomyelinase and act by reducing the total concentration of ceramide within endothelial cells and thereby also reduce the amount of ceramide released into the extracellular space of the hippocampus. The reduction of total ceramide by antidepressants counteracts the effects of glucocorticosterone on endothelial cells and thereby restores neurogenesis and prevents major depression. If this model is correct, amitriptyline should also prevent extraneural symptoms of major depressive disorder, for instance cardiovascular disease or osteoporosis.

In summary, our data show that stressed endothelial cells release ceramide into the extracellular space upon application of glucocorticosterone. Amitriptyline, an inhibitor of the acid sphingomyelinase and a commonly used antidepressant, prevents the release of ceramide. Ceramide inhibits proliferation of neuronal stem cells. These data suggest a novel model for the pathogenesis of major depressive disorder: Ceramide levels in endothelial cells of the neurogenetic zone regulate neurogenesis in the hippocampus. This model may also explain the systemic symptoms of many patients with major depressive disorder.

\section{Acknowledgements}

The study was supported to DFG grant GU 335/29-1 and NIH grant 2R01HL075316-09 to EG, DFG grant KO 947/13-1 to JK, BMBF-grant OPTiMD 01EE1401G and 01EE1401C to EG and JK, GRK 2098 to EG and HG and the Annika Liese Award 2014 to JK and EG.

\section{Disclosure Statement}

The authors have no conflicts to declare. 


\section{Cellular Physiology Cell Physiol Biochem 2016;39:790-801

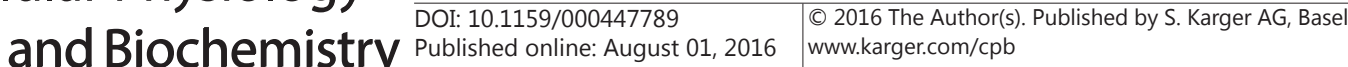 \\ Gulbins et al.: Endothelial Ceramide Regulates Hippocampal Stem Cells}

\section{References}

1 Belmaker RH, Agam G: Major depressive disorder. N Engl J Med 2008;358:55-68.

2 Grande I, Berk M, Birmaher B, Vieta E: Bipolar disorder. Lancet 2016;387:1561-1572.

3 Gulbins E, Walter S, Becker KA, Halmer R, Liu Y, Reichel M, Edwards MJ, Müller CP, Fassbender K, Kornhuber J: A central role for the acid sphingomyelinase/ ceramide system in neurogenesis and major depression. J Neurochemistry 2015;134:183-192.

4 Cizza G, Ravn P, Chrousos GP, Gold PW: Depression a major, unrecognized risk factor for osteoporosis? Trends Endocrinol Metab 2001;12:198-203.

5 Forlenza MJ, Miller GE: Increased serum levels of 8-hydroxy-2'-deoxyguanosine in clinical depression. Psychosom Med 2006;68:1-7.

6 Hibbeln JR, Palmer JW, Davis JM: Are disturbances in lipid-protein interactions by phospholipase-A2 a predisposing factor in affective illness? Biol Psychiatry 1989;25:945-961.

7 Howren MB, Lamkin DM, Suls J: Associations of depression with C-reactive protein, IL-1, and IL-6: a metaanalysis. Psychosom Med 2009;71:171-186.

8 Maes M, Smith R, Christophe A, Vandoolaeghe E, Van Gastel A, Neels H, Demedts P, Wauters A, Meltzer HY: Lower serum high-density lipoprotein cholesterol (HDL-C) in major depression and in depressed men with serious suicidal attempts: relationship with immune-inflammatory markers. Acta Psychiatr Scand 1997;95:212-221.

9 Musselman DL, Evans DL, Nemeroff CB: The relationship of depression to cardiovascular disease: epidemiology, biology, and treatment. Arch Gen Psychiatry 1998;55:580-592.

10 Nemeroff CB, Musselman DL, Evans DL: Depression and cardiac disease. Depress Anxiety 1998;8:S71-79.

11 Parker G, Gibson NA, Brotchie H, Heruc G, Rees AM, Hadzi-Pavlovic D: Omega-3 fatty acids and mood disorders. Am J Psychiatry 2006;163:969-978.

12 Gulbins E, Palmada M, Reichel M, Lüth A, Böhmer C, Amato D, Müller CP, Tischbirek CH, Groemer TW, Tabatabai G, Becker KA, Tripal P, Staedtler S, Ackermann TF, van Brederode J, Alzheimer C, Weller M, Lang UE, Kleuser B, Grassmé H, Kornhuber J: Acid sphingomyelinase-ceramide system mediates effects of antidepressant drugs. Nat Med 2013;19:934-938.

13 Hirschfeld RM: History and evolution of the monoamine hypothesis of depression. J Clin Psychiatry 2000;61:S4-6.

14 Brink CB, Harvey BH, Brand L: Tianeptine: a novel atypical antidepressant that may provide new insights into the biomolecular basis of depression. Rec Pat CNS Drug Discov 2006;1:29-41.

15 Jacobs BL, van Praag H, Gage FH: Adult brain neurogenesis and psychiatry: a novel theory of depression. Mol Psychiatry 2000;5:262-269.

16 Ernst A, Alkass K, Bernard S, Salehpour M, Perl S, Tisdale J, Possnert G, Druid H, Frisèn J: Neurogenesis in the striatum of the adult human brain. Cell 2014;156:1072-1083.

17 Spalding KL, Bergmann O, Alkass K, Bernard S, Salehpour M, Huttner HB, Boström E, Westerlund I, Vial C, Buchholz BA, Possnert G, Mash DC, Druid H, Frisén J: Dynamics of hippocampal neurogenesis in adult humans. Cell 2013;153:1219-1227.

18 Santarelli L, Saxe M, Gross C, Surget A, Battaglia F, Dulawa S, Weisstaub N, Lee J, Duman R, Arancio O, Belzung C, Hen R: Requirement of hippocampal neurogenesis for the behavioral effects of antidepressants. Science 2003;301:805-809.

19 Malberg JE, Eisch AJ, Nestler EJ, Duman RS: Chronic antidepressant treatment increases neurogenesis in adult rat hippocampus. J Neurosci 2000;20:9104-9110.

20 Videbech P, Ravnkilde B: Hippocampal volume and depression: a meta-analysis of MRI studies. Am J Psychiatry 2004;161:1957-1966.

21 Manji HK, Drevets WC, Charney DS: The cellular neurobiology of depression. Nat Med 2001;7:541-547.

22 Ekstrant J, Hellsten J, Tingström A: Environmental enrichment, exercise and corticosterone affect endothelial cell proliferation in adult rat hippocampus and prefrontal cortex. Neurosci Lett 2008;442:203207.

23 Sahay A, Hen R: Adult hippocampal neurogenesis in depression. Nat Neurosci 2007;10:1110-1115.

24 Henry B, Ziobro R, Becker KA, Kolesnick R, Gulbins E: Acid sphingomyelinase. Handb Exp Pharmacol 2013;215:77-88.

25 Schuchman EH: Acid sphingomyelinase, cell membranes and human disease: lessons from Niemann-Pick disease. FEBS Lett 2010;584:1895-1900.

26 Gulbins E, Kolesnick R: Raft ceramide in molecular medicine. Oncogene 2003;22:7070-7077.

27 Kornhuber J, Tripal P, Reichel M, Terfloth L, Bleich S, Wiltfang J, Gulbins E: Identification of new functional inhibitors of acid sphingomyelinase using a structure-property-activity relation model. J Med Chem 2008;1:219-237. 


\section{Cellular Physiology Cell Physiol Biochem 2016;39:790-801 \begin{tabular}{l|l|l|}
\hline DOI: 10.1159/000447789 & $\begin{array}{l}\text { C) } 2016 \text { The Author(s). Published by S. Karger AG, Basel } \\
\text { www.karger.com/cpb }\end{array}$ \\
\hline Published online: August 01, 2016
\end{tabular} \\ Gulbins et al.: Endothelial Ceramide Regulates Hippocampal Stem Cells}

28 Snyder JS, Soumier A, Brewer M, Pickel J, Cameron HA: Adult hippocampal neurogenesis buffers stress responses and depressive behaviour. Nature 2012;476:458-461.

29 de Kloet ER, Vreugdenhil E, Oitzl MS, Joels M: Therapy insight: is there an imbalanced response of mineralocorticoid and glucocorticoid receptors in depression? Nat Clin Pract Endocrinol Metab 2007;3:168-179.

30 Hurwitz R, Ferlinz K, Sandhoff K.: The tricyclic antidepressant desipramine causes proteolytic degradation of lysosomal sphingomyelinase in human fibroblasts. Biol. Chem. Hoppe Seyler 1994;375:447-450.

31 Kölzer M, Werth N, Sandhoff K: Interactions of acid sphingomyelinase and lipid bilayers in the presence of the tricyclic antidepressant desipramine. FEBS Lett 2004;559:96-98.

32 Nojima H, Freeman CM, Schuster RM, Japtok L, Kleuser B, Edwards MJ, Gulbins E, Lentsch AB: Hepatocyte exosomes mediate liver repair and regeneration via sphingosine-1-phosphate. J Hepatol 2016;64:60-68.

33 Laitinen L: Griffonia simplicifolia lectins bind specifically to endothelial cells and some epithelial cells in mouse tissues. Histochem J 1987;19:225-234.

34 Bianco F, Perrotta C, Novellino L, Francolini M, Riganti L, Menna E, Saglietti L, Schuchman EH, Furlan R, Clementi E, Matteoli M, Verderio C: Acid sphingomyelinase activity triggers microparticle release from glial cells. EMBO J 2009;28:1043-154.

35 Horstman LL, Jy W, Bidot CJ, Nordberg ML, Minagar A, Alexander JS, Kelley RE, Ahn YS: Potential roles of cell-derived microparticles in ischemic brain disease. Neurol Res 2009;31:799-806.

36 Joshi P, Benussi L, Furlan R, Ghidoni R, Verderio C: Extracellular vesicles in Alzheimer's disease: friends or foes? Focus on a $\beta$-vesicle interaction. Int J Mol Sci 2015;16:4800-4813.

37 Trajkovic K, Hsu C, Chiantia S, Rajendran L, Wenzel D, Wieland F, Schwille P, Brügger B, Simons M: Ceramide triggers budding of exosome vesicles into multivesicular endosomes. Science 2008;319:1244-1247.

38 Tsai WH, Lai SL, Li IT, Chien HY, Shih CH, Kou YR, Hsu HC: Annexin A1 mediates the anti-adhesive effects of the dexamethasone-treated promyelocytic leukemic cells. J Cell Biochem 2013;114:551-557.

39 Zhu JY, Zhang W, Ren JG, Chen G, Zhao YF: Characterization of Endothelial Microparticles Induced by Different Therapeutic Drugs for Infantile Hemangioma. J Cardiovasc Pharmacol 2015;66:261-269.

40 Chatterjee S: Sphingolipids in atherosclerosis and vascular biology. Arterioscler Thromb Vasc Biol 1998;18:1523-1533.

41 Li X, Becker KA, Zhang Y: Ceramide in redox signaling and cardiovascular diseases. Cell Physiol Biochem 2010;26:41-48.

42 Pavoine C, Pecker F: Sphingomyelinases: their regulation and roles in cardiovascular pathophysiology. Cardiovasc Res 2009;82:175-183.

43 Gulbins E, Li PL: Physiological and pathophysiological aspects of ceramide. Am J Physiol Regul Integr Comp Physiol 2006;290:R11-26.

44 Larsen SD, Wilson MW, Abe A, Shu L, George CH, Kirchhoff P, Showalter HD, Xiang J, Keep RF, Shayman JA: Property-based design of a glucosylceramide synthase inhibitor that reduces glucosylceramide in the brain. J Lipid Res 2012;53:282-291.

45 Shibuya M, Claesson-Welsh L: Signal transduction by VEGF receptors in regulation of angiogenesis and lymphangiogenesis. Exp Cell Res 2006;312:549-560.

46 Kiuchi T, Lee H, Mikami T: Regular exercise cures depression-like behavior via VEGF-Flk-1 signaling in chronically stressed mice. Neuroscience 2012;207:208-217.

47 Truman JP, García-Barros M, Kaag M, Hambardzumyan D, Stancevic B, Chan M, Fuks Z, Kolesnick R, Haimovitz-Friedman A: Endothelial membrane remodeling is obligate for anti-angiogenic radiosensitization during tumor radiosurgery. PLoS One 2010;5:e12310.

48 Kirby ED, Kuwahara AA, Messer RL, Wyss-Coray T: Adult hippocampal neural stem and progenitor cells regulate the neurogenic niche by secreting VEGF. Proc Natl Acad Sci USA 2015;112:4128-4133.

49 Lang UE, Beglinger C, Schweinfurth N, Walter M, Borgwardt S: Nutritional aspects of depression. Cell Physiol Biochem 2015;37:1029-1043.

50 Mühle C, Amova V, Biermann T, Bayerlein K, Richter-Schmidinger T, Kraus T, Reichel M, Gulbins E, Kornhuber J: Sex-dependent decrease of sphingomyelinase activity during alcohol withdrawal treatment. Cell Physiol Biochem 2014;34:71-81.

51 Reichel M, Richter-Schmidinger T, Mühle C, Rhein C, Alexopoulos P, Schwab SG, Gulbins E, Kornhuber J: The common acid sphingomyelinase polymorphism p.G508R is associated with self-reported allergy. Cell Physiol Biochem. 2014;34:82-91.

52 Grassmé H, Riethmüller J, Gulbins E: Biological aspects of ceramide-enriched membrane domains. Prog Lipid Res 2007;46:161-170.

53 Grassmé H, Jekle A, Riehle A, Schwarz H, Berger J, Sandhoff K, Kolesnick R, Gulbins E: CD95 signaling via ceramide-rich membrane rafts. J Biol Chem 2001;276:20589-20596. 